\title{
The Analysis of Heavy Metal Lead (Pb) on Oyster Crassostrea Cucullata and Fishing Port Waters of Mayangan Beach Probolinggo
}

\author{
${ }^{1}$ Pramusyawardhani, G. ${ }^{2}$ Arfiati, ${ }^{3}$ D, Soeprijanto, A. \\ ${ }^{I}$ (Graduate Program, Faculty of Fisheries and Marine Sciences UB) \\ ${ }^{2,3}$ (Lecturer, Faculty of Fisheries and Marine Sciences UB)
}

\begin{abstract}
Oyster C. cucullata is one of the potential species contaminated by heavy metal due to its way of eating, namely by filtering the water. In addition, the oyster character that tends to settle (sessile) and does not migratory organism. This study aims to know the content of heavy metal heavy metal Pb on the sea water and oyster C. cucullata from the Fishery Port of Mayangan Beach. The study uses survey method by using for stations; station I is the mooring dock, station II is Fish Auction, station III is mangrove area, and station IV is Bentar beach. The data collected from several phases of the experiments was analyzed descriptively to know the content of heavy metal Pb in waters and oyster $C$. cucullata. The result of the study shows that the content of heavy metal Pb in the sea water is approximately in the range of $0.023 \mathrm{ppm}-0.041 \mathrm{ppm}$. Whereas the heavy metal $\mathrm{Pb}$ in the oyster C. cucullata is in the range of $0.6500 \pm 0,713 \mathrm{ppm}-1,528 \pm 0,157 \mathrm{ppm}$. By the mean of bioindicator of oyster C. Cucullata, it shows that the Fishing Port water of Mayangan Beach has been contaminated heavy metal Pb oyster C. cucullata.
\end{abstract}

Keywords: Heavy metal Pb, oyster C. cucullata, bio-indicator,

\section{Introduction}

Offshore Fishing Port Mayangan in Mangunharjo village, sub district Mayangan, Probolinggo has 40 hectares, around $1 \mathrm{~km}$ from Tanjung Tembaga Port. Nowadays, Mayangan is the biggest fishing port in East Java, having a $483,000 \mathrm{~m}^{3}$ port pool and enabling big ships over $30 \mathrm{GT}$ to harbor. This port is used to harbor the fishing ships, land the fish, and ease the activities of fishing ship. The best result of the fish landed in Port Mayangan was in 2008 which was 43,021 ton. In addition, the Offshore Fishing Port Mayangan is also used to market and distribute the haul, the implementation of result quality couching of the haul as well as counseling and fishing data collection [8].

The high activity found in Mayangan Port effects on the quality of the water and biota due to the waste of the ships and solar use as the fuel and the use of oil as the engine lubricant. Used engine lubricant is B3 waste that contains heavy metal, one of which is lead $(\mathrm{Pb})$. The negative impact of pollutant threw to the waters will cause changes on physical, chemical, and biological characters of the water. Heavy metal of lead is biocumulative upon organism in the water. The average need of diesel fuel in the Fish Auction of Mayangan according to the data from UPDT TPI Mayangan in 2012 was 14057.91 liter and kerosene 455.67 liter.

The fishing port water of Mayangan beach Probolinggo has a potential natural source of oyster $C$. cucullata that is used by the society for foods. Oyster is a bivalve whose movements are so slow, which settles down in particular area in the water base, and eats by filtering the particles in the water-called filter feeder [1]; [11]. Thus, it causes the bivalve can accumulate the metal greater that other water animals, so that this biota is frequently used in the monitoring of the heavy metal contamination level in the waters. The heavy metal that enters into organism will cause poisoning and death [9].

According to the environmental status in Probolinggo in 2009, it was found that the level of lead in the sea water was 0,0053 $\pm 0,003 \mathrm{ppm}$ [2]. An introductory study in December 2010 in fishing port of Mayangan beach showed that the lead $(\mathrm{Pb})$ level in the sea water was $0.0172 \mathrm{ppm}$. The level of heavy metal Lead $(\mathrm{Pb})$ in the port area was suspected to cause contamination in Oyster $C$. cucullata tissue, so it requires a bio-monitoring upon heavy metal Lead $(\mathrm{Pb})$ pollution in the Fishing port of Mayangan beach.

This study aims to know the level of heavy metal Lead $(\mathrm{Pb})$ in the Fishing Port water of Mayangan beach Probolinggo and C. cucullata. As the result, this study is expected to be able to provide information about the existence of heavy metal Lead $(\mathrm{Pb})$ in the Fishing Port of Mayangan beach Probolinggo, as well as give contribution for the local government and the related parties in monitoring and handling the management of the environment due to the water pollution. 


\subsection{Place and Time}

\section{Material And Method}

This study was conducted in the Fishing Port water of Mayangan beach and Biochemical Laboratory of FMIPA of Brawijaya University of Malang. It was taken place in November 2012 - January 2013.

\subsection{Method of the Study}

This study was conducted by using survey and data methods, gained and analyzed descriptively. The data collection technique was conducted by purposive random sampling in 4 stations with 3 points and 5 repetitions. According to [5], purposive random sampling is a random sample collection in which the sample is taken for particular purposes.

\subsection{Determination of the Station}

The water and oyster samples were taken in four stations, namely Station I (Mooring dock) that was a part of the port which was used to harbor for the ships and a place in which there was SPDN ( Engine Lubricant Package Dealer for Fishermen), Station II (Fishing Auction/TPI) that was a part of the port that was used to unload the haul to be sold in Fishing Auction - in which there were many food stalls for fishermen and fish market, Station III that was a mangrove area, and Station IV (Bentar Beach/a tourism object) that was a tourism object that had a dense mangrove forest (Appendix 1). The determination of the sampling stations was based on the pollutant from the different waste source. In Station I, the waste source was from the oil waste of the ships or ships reparations. Station II, the waste source was from Fish Auction or market. Station III, the waste source was from domestic waste that uses river as the waste place. Station IV was the maritime tourism area and fisheries.

\subsection{Measurement of Heavy metal Pb level in the water and oyster}

The sample $\mathrm{f}$ water was collected from each station by using sample bottle, and then it was preserved with $\mathrm{HNO}(\mathrm{pH}<2)$. The oyster sample was collected from stone by detaching the oyster by using sledge hammer or hammer. Oyster samples collected from each station were then saved in the paper bag without being tied, marked, and kept in contained basket. In laboratory, these samples were washed to clean the sand, mud, and stone residue that were still attached to the oysters. Next, a gastric sample preparation was conducted to analyze the heavy metal $\mathrm{Pb}$ level (EPA). The measurement of heavy metal $\mathrm{Pb}$ in the water and oysters samples was conducted by using AAS method [14].

\section{Level of Heavy Metal Pb in the Sea Water}

\section{Result And Discussion}

The level of heavy metal Lead $(\mathrm{Pb})$ in Station I (mooring dock) is $0.041 \mathrm{ppm}$, Station II (Fishing Auction) is $0.029 \mathrm{ppm}$, Station III (mangrove) is $0.023 \mathrm{ppm}$, and Station IV (Bentar Beach) is $0.035 \mathrm{ppm}$ (Picture 1). Based on the Stipulation of the Environmental Ministry Number 51 Year 2004 and Decree of Environmental Ministry Number 179 Year 2004, the level of $\mathrm{Pb}$ in the sea water of which are $0.008 \mathrm{ppm}$ and $0.05 \mathrm{ppm}$. This shows that the level of heavy metal $\mathrm{Pb}$ in all stations is still under the threshold which is applied for the sea water. The low level of heavy metal $\mathrm{Pb}$ in Station III compared to the others is due to the mangrove area in this station. According to [3]; [10] ; [12], mangrove can be used as the pollutant trap that can absorb the pollutant in the sediment or water through mangrove roots.

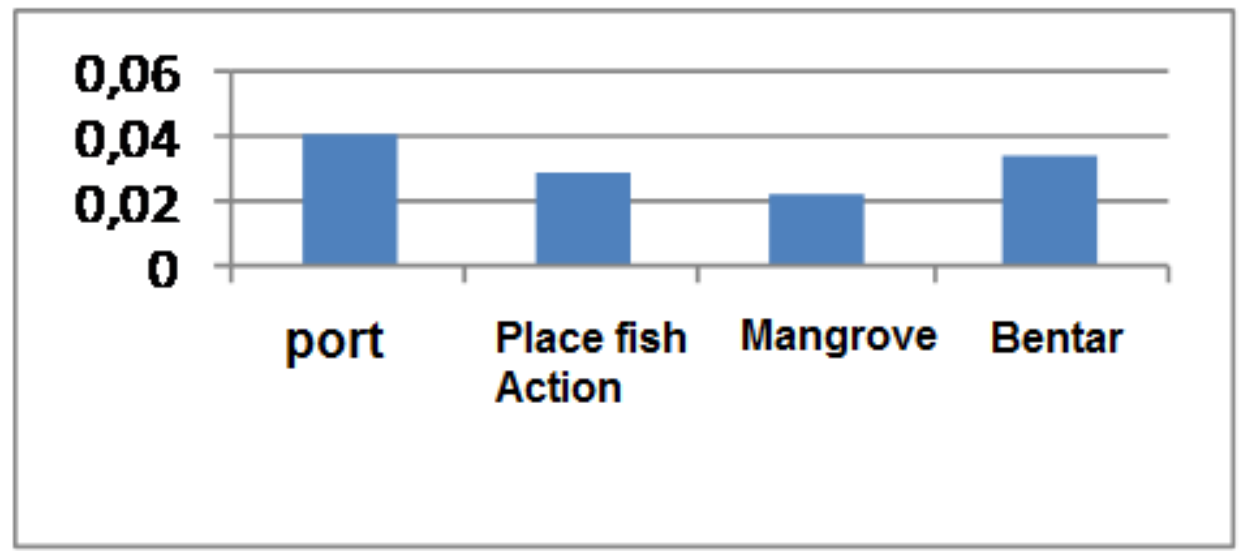

Figure 1. Diagram of Level of Heavy Metal $\mathrm{Pb}$ in the waters 
The existence of heavy metal $\mathrm{Pb}$ in the Fishing Port waters of Mayangan is due to the ships activities that produce fuel residue of the motorboat and ships' paintings. The fishing motorboat was always started 1 hour earlier before departing. Therefore, it causes the smoke waste entered the port waters. In addition, the muffler (gas residue of the fuel ignition) was located under the boat or near the sea water surface, resulting the gas waste directly interacted with the sea water and contributed the contamination in the waters. [13]; [16].

The existence of heavy metal $\mathrm{Pb}$ in Bentar beach water was from the activities of tourism ships and fishing ships of the fishermen. Although the ship activities in this area were not as high as the ship activities in Fishing Auction of Mayangan, it still contributed the production of $\mathrm{Pb}$ level in the sea water.

\subsection{Level of Heavy Metal Pb in Oysters}

The level of heavy metal in Oyster $C$. cucullata in each station were 1,528 $\pm 0,157 \mathrm{ppm}$ in Mooring

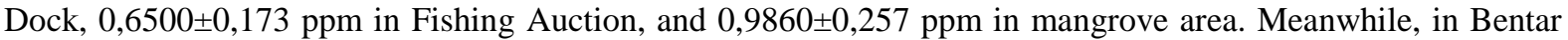
Beach it was 0,7620 $\pm 0,339 \mathrm{ppm}$ (Picture 2). The absorption of heavy metal $\mathrm{Pb}$ in oysters' gastric was different from each station. In Station I, the oyster's gastric respond upon $\mathrm{Pb}$ was higher than in Station II, III, and IV. The level of $\mathrm{Pb}$ in oysters' gastric was relatively high compared to in the water. Thus, it shows that $\mathrm{Pb}$ in the water has been accumulated in the body of biota monitored. The high level of heavy metal $\mathrm{Pb}$ in oysters' gastric in Station I was caused by the high activities of the ships around this area which was a mooring dock.



Figure 2. Diagram of Level of Heavy Metal $\mathrm{Pb}$ in the Gastric of Oyster C. cucullata

Metal $\mathrm{Pb}$ entered through portal entry surface of the respiration organ, namely gill and mantle along with water of phytoplankton. The gill filtered the water that contained pollutant and entered the oyster body and was distributed around the body afterward through the blood circulation; and finally was accumulated in the organs such as digestion (gastric), muscle, etc [7]; [1].

The level of heavy metal $\mathrm{Pb}$ in the oysters from four observations were still under the maximum threshold of the Directorate general of Medicine and Foods Monitoring (POM) Number 03725/B/SK/VII/89 that limits the level of heavy metal $\mathrm{Pb}$ in the natural resources of fish and its dairies which is $2.0 \mathrm{mg} / \mathrm{l}$. Heavy metal $\mathrm{Pb}$ that entered the oyster body simultaneously would cause changes or destructions of cell structure in its body, [6]. The factors accumulated in each sea biota was relatively different due to the different biological natures (type, age, and physiologic) of each biota, as well as the different physical and chemical natures and activities of each location [17]; [15. Furthermore, according to [4], the toxity of the heavy metal upon organism totally depended on the species, location, age, life cycle phase, immune (detoxification), and the individual ability to avoid pollution impacts.

\subsection{Conclusion}

\section{Conclusion And Suggestion}

1. The level of heavy metal Lead $(\mathrm{Pb})$ in the Fishing Port Water of Mayangan Beach Probolinggo was in the range of 0,023 ppm - 0,041 ppm. The level of heavy metal Lead was still under the threshold of the Stipulation of the Environmental Ministry Number 51 Year 2004 and Decree of Environmental Ministry Number 179 Year 2004, the level of $\mathrm{Pb}$ in the sea water of which are $0.008 \mathrm{ppm}$ and was revised by Stipulation Number 179 year 2004 on Quality Standard of Sea Water, namely $0.05 \mathrm{mg} / \mathrm{l}$.

2. The level of heavy metal Lead $(\mathrm{Pb})$ in oyster $C$. cucullata from Fishing Port Water of Mayangan Beach was in the range of $0,6500 \pm 0,173 \mathrm{ppm}-1,528 \pm 0,157 \mathrm{ppm}$. This level was still under the maximum threshold of Directorate general of Medicine and Foods Monitoring (POM) Number 03725/B/SK/VII/89 that limits the level of heavy metal $\mathrm{Pb}$ in the natural resources of fish and its dairies which is $2.0 \mathrm{mg} / \mathrm{l}$. 


\section{2. $\quad$ Suggestion}

Based on the result of the study, it shows that C. cucullata in the Fishing Port Water of Mayangan Beach has been contaminated by heavy metal Lead, although it is still under the stimulated quality standard; however, it needs concern from the government and local society concerning that this Crassostrea cucullata is consumed as food. In addition, the Installation of Waste Water Process (IPAL) needs to be improved and the regulation of ship waste disposal by the local government needs to be asserted.

\section{References}

[1] Arfiati, D. 2007. Kemampuan Tiga Jenis Tiram dalam Biofilter Fitoplankton. Disertasi. Universitas Brawijaya Program Pasca Sarjana. Malang.

[2] Anonymous, 2009. Buku Data status Lingkungan Hidup Daerah Kota Probolinggo Tahun 2009. Pemerintah Kota Probolinggo provinsi Jawa Timur.

[3] Dahuri, R, Rais, J, Ginting S, P. dan Sitepu, M. J, 1996. Pengolahan Sumberdaya Pesisir dan Lautan Secara Terpadu. PT. Pradnya Paramitha. Jakarta.

[4] Darmono. 2001.Lingkungan Hidup dan Pencemaran. Jakarta : UI PRESS.

[5] EPA (Environment Pollution Association), 1973. Water Quality Criteria. Ecol.Res.Series, Washington. 595p

[6] Gagnaire, B.Thomas-Guyon, H. Renault, T. 2004. In Vitro Effect of Cadmium and Mercury on Pasific Oyster, Crassostrea gigas (Thunberg), Haemocytes. Fish \& Shellfish Immunology, 16 (4) : 501-512.

[7] Galtsoff, P, S. 1964. The American Oyster ( Crassostrea virginica). Gmelin Fishery Buletin Of The Fish And Wildlife Service, Vol. 64. In US. Departement of Interior Fish and Wildlife Service, Burean of Commercial Fisheries. P 219 - 238.

[8] Keputusan Menteri Negara Lingkungan Hidup, 2004. Baku Mutu Air Laut untuk Biota Laut. Kementerian Negara Lingkungan Hidup

[9] Kominfo Jatim. Ambolnya Breakater Mayangan. http// Kominfo. JatimProv.go.id. diakses Februari, 2010

[10] Maryani, D. Dana, Sukenda, 2002. Peranan ekstrak kelopak dan buah mangrove sonneratia caseolaris terhadap infeksi bakteri vibrio harveyi pada udang windu (Penaeus monodon FAB.). Jurnal Akuakultur Indonesia, 1(3) : 129-138.

[11] Murtini, J, T., Yennie, Y., Peranginangin, R. 2003. Kandungan Logam Berat pada Kerang Darah ( Anadara granosa ), Air laut dan Sedimen di Perairan Tanjung Balai dan Bagan.

[12] Raymon, G, P. 2010. Studi Pengelolaan Hutan Mangrove Berbasis Masyarakat di Kecamatan Gending, Kabupaten Probolinggo, Jawa Timur. Tesis Program Pasca Sarjana Fakultas Perikanan Universitas Brawijaya. Malang

[13] Siaka, I.M. 2008. Korelasi Antara Kedalaman Sedimen Di Pelabuhan Benoa dan Konsentrasi Logam Berat Pb dan Cu. Jurnal Kimia, 2 (2) : 61-70.

[14] Su, G.S., K. J. Martillano, T.P. Alcantara, E. Ragragio., D. Josephina, A. Hallare. and G. Ramos. 2009. Assessing heavy metals in the waters, fish and macroinvertebrates in Manila Bay, Philippines. Journal of applied sciences in environmental sanitation.

[15] WHO HECA. Issue Brief Series : Lead. Http;//www. WHO.Int/heca/. Html. Di akses Desember 2012.

[16] Wulandari, E. 2010. Analisis Kandungan Logam Berat Timbal (Pb) dan Karakteristik Haemocyte Tiram (Saccostrea Glomerata) dari Perairan Pelabuhan Perikanan Nusantara Prigi Trenggalek, Jawa Timur. Universitas Brawijaya. Malang. Skripsi Fakultas Perikan Universitas Brawijaya. Malang

[17] Yudha, I.G. 2007. Kajian Pencemaran Logam Berat di Wilayah Pesisir Kota bandar Lampung. Seminar Hasil Penelitian \& Pengabdian Kepada Masyarakat. Fakultas Perikanan Universitas Lmapung. 